\title{
Plant economy and village life in Neolithic lake dwellings at the time of the Alpine Iceman
}

\author{
Stefanie Jacomet
}

Received: 24 August 2007/ Accepted: 11 October 2007/Published online: 10 January 2008

(C) Springer-Verlag 2008

\begin{abstract}
This paper gives an overview of domesticated and wild plants used during the second half of the fourth millennium cal B.C. in a region within a semicircle of ca. $100 \mathrm{~km}$ radius around the find site of the Iceman. The landscape considered lies north of the main Alpine chain and includes central to eastern Switzerland and southwest Germany, mainly sites at the lakes Zug, Zürich, Constance (Bodensee), the Federsee region of Upper Swabia (Oberschwaben) and western Bavaria. From this part of central Europe, the plant remains of many well-preserved lake dwelling sites have been investigated during the last decades and much is known about daily life in these villages. Probably contemporary with the Iceman's lifetime is one of the best-investigated settlements, Arbon Bleiche 3 on the southern shore of Lake Constance. A comparison of the Iceman's artefacts and plant macro remains with the finds from the lake dwellings which have been studied shows striking similarities, but also differences. The Iceman's southern provenance can be corroborated by the domestic plants found with him. He used domestic as well as wild plants, very similar to those of his contemporaries in the lakeside villages. The detailed knowledge of the manifold activities in the lakeshore village of Arbon Bleiche 3 allows us to show a rather realistic picture of daily life at the time of the Iceman.
\end{abstract}

Keywords Late Neolithic - Germany - Switzerland . Italy · Waterlogged preservation · Plant macro remains

S. Jacomet $(\bowtie)$

Institute for Prehistory and Archaeological Science IPAS, Basel University, Spalenring 145, 4055 Basel, Switzerland e-mail: stefanie.jacomet@unibas.ch

\section{Introduction}

The investigations of the Iceman have provided us many detailed facts about his clothes, his last meal and his last journey (Höpfel et al. 1992; Spindler et al. 1995, 1996; Bortenschlager and Oeggl 2000; Dickson et al. 2005; Oeggl et al. 2008; Heiss and Oeggl 2008, this volume). Many of these details, mainly concerning clothing and equipment were not known before (or at least not in detail) and added very much information on how a late Neolithic male individual may have looked and was equipped. But almost nothing is known of the place in northern Italy where the Iceman lived and what his life circumstances may have been. Main aim of this paper is to shed some new light on Neolithic lifestyles by presenting results of contemporary settlements, excavated at a rather small distance to the north and northwest of the Iceman's find-site. The archaeobotanical remains have not been studies up till now (for a comparison of the equipment see, for example, Matuschik and Schlichtherle 2001).

For three decades, many investigations of well-preserved plant material from lake dwelling sites north of the Alpine chain have been performed (for recent overviews see the publications of Jacomet 2006, 2007, submitted; Fig. 1). The preservation of the settlement layers is excellent, due to waterlogging. Therefore, our knowledge of the economy and daily life in general between ca. 4300 and 2500 cal B.C. is rather good, compared with other regions. However, the state of research is not as excellent as it seems to be on the first sight because many of the over 90 investigated settlements have not been analysed in a representative way (for a critical review see Jacomet and Brombacher 2005).

The Iceman died between 3320 and 3050 cal B.C. (Kutschera and Müller 2003). Recently it was suggested by 


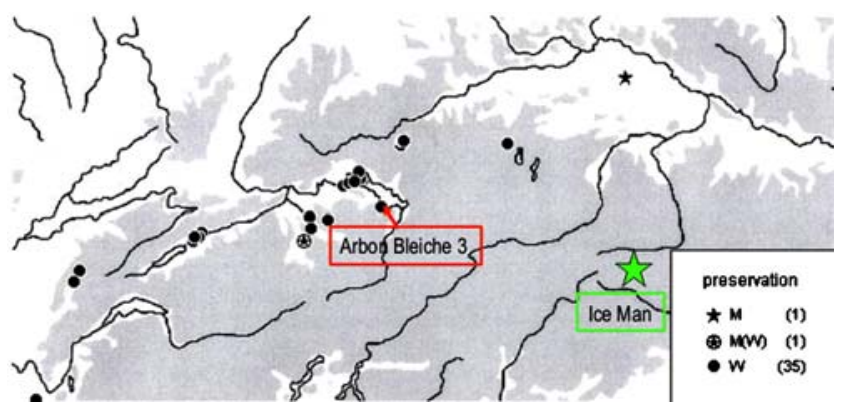

Fig. 1 Map of the area under consideration in this study, including the find spot of the Iceman. M, settlement on mineral soil, only carbonised remains preserved; $\mathrm{M}(\mathrm{W})$, originally waterlogged settlement which dried out; $\mathrm{W}$, waterlogged preservation

Magny and Haas (2004) that his death and above all his preservation through quick burial is to be seen in connection with a climatic deterioration which happened suddenly after a short period of favourable climatic conditions in the 34th century cal в.с. From this particular period, however, we unfortunately know of only a very few lakeshore settlements (Table 1). This is because prevailing high lake levels between 3550 and (at least) 3300 cal B.c. made it difficult to settle on those lake shore sites where preservation would have been possible later on (Magny and Haas 2004). By chance, in the 1990s a large and well-preserved settlement of the 34th century cal B.C., Arbon Bleiche 3, was excavated on the southern shore of Lake Constance (Switzerland, canton of Thurgau). This village existed between 3384 and 3370 в.c. (dated by dendrochronology; Leuzinger 2000; Sormaz 2004). The ground plans of 27 houses are known and the building year of each of the buildings could be reconstructed. Between 1997 and 2004 the finds from this village were evaluated in an interdisciplinary project (De Capitani et al. 2002; Jacomet et al. 2004). Therefore we know rather exactly how people lived during the life time of the Iceman around $100 \mathrm{~km}$ to the northwest of his find spot. In the following we will also give a short summary of the main results of the Arbon Bleiche 3 investigations.

Besides Arbon Bleiche 3, there are only five settlements of the 34th century в.c. located in the region considered here from which we have archaeobotanical data (Table 1). From these settlements mostly unrepresentative data exist. Nonetheless, their results are included here. In addition we decided to include data from two earlier settlements in western Bavaria (Pestenacker, Galgenberg), one settlement which existed around 3400 cal B.C. at Bielersee (Nidau BKW) and some later settlements (3300-3000 cal в.с.). Their basic data are listed in Table 1. The reason for including those settlements is to see how the data of the 34th and 33rd centuries B.c. fit into the general picture of the second half of the fourth millennium B.c.

\section{Materials and methods}

For a comparison with the data of the Iceman's mummy and his find site, the data from the settlements have been compiled. As shown in Table 1, the sample numbers differ greatly from site to site. There are representative investigations from only rather few sites. The expression "representatively investigated" is understood in terms of settlements from which we have reliable knowledge of the intra-site patterns; this is only very rarely the case (representativeness category 1 in Table 1; for more details see the publications of Jacomet and Brombacher 2005; Jacomet 2006). Fortunately, the settlement which is probably contemporary with the Iceman, Arbon Bleiche 3, is one of the category 1 sites where systematic surface sampling took place and several houses were sampled.

Because the dataset used is extremely heterogeneous, an attempt has been made to standardize (simplify) the data based on a system of scores (according to Robinson 2003, p 148). The cereal finds were summed and then scored on a scale from 4 to 1 , according to their importance at each site ( 4 = dominant, 1 st place; $3=$ major component, 2 nd place; $2=$ many to some remains, 3 rd place; $1=$ few remains or present, 4th place). In Figs. 2 and 3 this is shown by bars. When interpreting the data we also consider ubiquities which, however, are not listed in the figures.

The counts of remains of various other cultivated and gathered plants are similarly not directly comparable. Ideally, concentrations of remains per liter of sediment should be compared, at least for the waterlogged layers. This is, however, not possible, on the one hand, because these data are only rarely published and, on the other, because-depending on the sieving procedure-some of the remains are more subjected to damage than others (see Hosch and Zibulski 2003). In addition, the quantification of fragments is heterogeneous. Accordingly, the discussion should be based mainly on presence versus absence of all the remaining taxa. However, we tried at least to score the remaining domestic plants in a simplistic way (details see Fig. 3) for visualizing their importance during the second half of the fourth millennium cal в.c. For the collected plants from natural vegetation, Table 2 shows the raw data (total counts of finds).

Almost all the settlements included here show waterlogged preservation, therefore most of the plant parts are preserved in subfossil state, but there are also carbonised remains. The same holds also for the Iceman where preservation through freezing is even better. More problematic are comparisons with sites on dry mineral soils. Here, we have to reckon with the under-representation of many plants, especially oil plants and collected fruits (for the methodological background, see Willerding 1991). The presence of cereals and pulses, however, is most probably comparable. 
Table 1 List of settlements considered in this article, according to their dates, with the latest settlements on the top

\begin{tabular}{|c|c|c|c|c|c|c|c|c|}
\hline 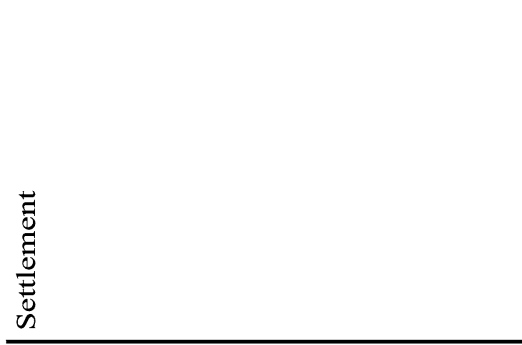 & 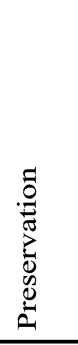 & 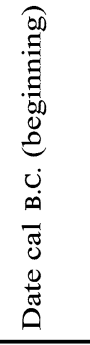 & 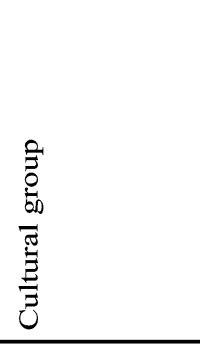 & 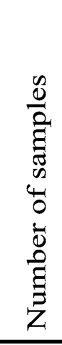 & 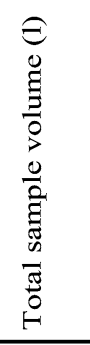 & 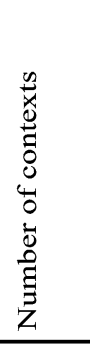 & $\begin{array}{l}n \\
0 \\
0 \\
0 \\
0 \\
: \\
0 \\
0 \\
0 \\
0 \\
0 \\
0 \\
0 \\
0 \\
0 \\
0 \\
0\end{array}$ & 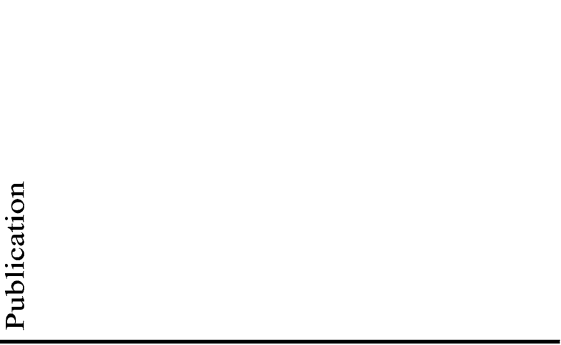 \\
\hline Hadersbach (D) Kr. Straubing-Bogen & $\mathrm{D}$ & 3000 & Cham & 4 & 16 & 16 & ? $\mathrm{K}$ & Küster 1995 \\
\hline Seekirch (D) Stockwiesen, Kr. Biberach & W & 3030 & Horgen/Goldberg & II 40 & 8 & 40 & $4 \mathrm{M}$ & Maier 2004 \\
\hline Zug ZG Vorstadt 26, Rössliwiese & $\mathrm{W}(\mathrm{D})$ & 3050 & Horgen & 1 & 2.5 & 1 & $5 \mathrm{Ja}$ & Jacomet and Wagner 1987 \\
\hline Horgen ZH Scheller 3 & $\mathrm{~W}$ & 3061 & Horgen & 41 & 38.2 & $>22$ & $1 \mathrm{Fr}$ & Favre 2001, 2002 \\
\hline Horgen ZH Scheller 4 & $\mathrm{~W}$ & 3078 & Horgen & 21 & 20.7 & 21 & $1 \mathrm{Fa}$ & Favre 2001, 2002 \\
\hline Pfäffikon ZH Burg & $\mathrm{W}$ & $3100 ?$ & Horgen & 57 & 210 & 67 & $2 \mathrm{Zi}$ & Zibulski unpubl. \\
\hline Zürich Mozartstrasse Schicht 3 & $\mathrm{~W}$ & 3126 & Horgen & 139 & 968 & 75 & $3 \mathrm{Ja}$ & Jacomet et al. 1989 \\
\hline Zürich KanSan Schicht 2 & $\mathrm{~W}$ & 3126 & Horgen & 53 & 27 & 46 & $3 \mathrm{~B}$ & Brombacher and Jacomet 1997 \\
\hline Allensbach (D) Strandbad unt. Schicht B & $\mathrm{W}$ & $3150 ?$ & Horgen & 8 & 24 & 3 & $5 \mathrm{~K}$ & Karg 1990 \\
\hline Twann BE mittl. Horgener KS & $\mathrm{W}$ & 3176 & Lattrigen, late & 8 & $>0.1$ & 1 & $5 \mathrm{Pi}$ & Piening 1981; Furger 1980 \\
\hline Hornstaad (D) V südl. Pfahlfeld & $\mathrm{W}$ & 3176 & Horgen? & 16 & 11.6 & 16 & 3 ? $\mathrm{Ri}$ & Rösch 1990 \\
\hline Zürich KanSan Schicht 3 & $\mathrm{~W}$ & 3179 & Horgen & 36 & 27 & 27 & $2 \mathrm{~B}$ & Brombacher and Jacomet 1997 \\
\hline Sipplingen (D) Osthafen, Schicht 12-14 = u/m & $\mathrm{W}$ & $3200 ?$ & Horgen & 6 & 10.7 & 1 & $5 \mathrm{Ja}$ & Jacomet 1990 \\
\hline Galgenberg (D), Pfarrkirchen Kr. Rottal-Inn & $\mathrm{D}$ & $3200 ?$ & Cham & 25 & 176 & $>9$ & ? $\mathrm{H}$ & Hinton 1999 \\
\hline Zürich KanSan Schicht 4 & $\mathrm{~W}$ & 3239 & Horgen & 48 & 22.5 & 39 & $2 \mathrm{~B}$ & Brombacher and Jacomet 1997 \\
\hline Zürich Mythenschloss Schicht 3 & $\mathrm{~W}$ & 3240 & Horgen & 10 & 1.2 & 5 & $5 \mathrm{Ja}$ & Jacomet et al. 1989; Brombacher and Jacomet 1997 \\
\hline Torwiesen II (D) Bad Buchau, Kr. Biberach & W & 3293 & Horgen & 46 & 21 & 46 & $4 \mathrm{H}$ & Herbig 2002, 2006 \\
\hline Oberrieden ZH Riet & $\mathrm{W}$ & $3300 ?$ & Horgen, early & 13 & $1 \mathrm{ca}$ & $1 ?$ & $5 \mathrm{Ja}$ & Jacomet 2004 \\
\hline Sipplingen (D) Osthafen, Schicht $11=u$ & $\mathrm{~W}$ & 3316 & Horgen? & 1 & 2 & 3 & $5 \mathrm{Ja}$ & Jacomet 1990 \\
\hline Wallhausen (D) Ziegelhütte, Kr. Konstanz & $\mathrm{W}$ & 3350 & Horgen & 5 & k.A. & 1 & $5 \mathrm{R}$ & Rösch 1990 \\
\hline Ice Man (I), Hauslabjoch, Schnalstal & $\mathrm{W}$ & 3320 & & & & & & Oeggl table, unpubl. \\
\hline Wangen (D) Hinterhorn Kr. Konstanz & $\mathrm{W}$ & 3371 & Horgen & 16 & 8 & 1 & $5 \mathrm{Ri}$ & Riehl 1993 and unpubl. \\
\hline Arbon TG Bleiche 3 Flächenproben & $\mathrm{W}$ & 3384 & Pyn/Horgen & 73 & 340 & 73 & $1 \mathrm{H}$ & Hosch 2003; Hosch and Jacomet 2004 \\
\hline Hornstaad (D) V nördl. Pfahlfeld Kr. Konstanz & $\mathrm{W}$ & $3400 ?$ & Horgen? & 11 & 4.8 & 11 & $5 \mathrm{R}$ & Rösch 1990 \\
\hline Nidau BE Schlossmatte BKW Ib, Schicht 5 & $\mathrm{~W}$ & 3406 & Lattrigen, early & 27 & 23.5 & 24 & $2 \mathrm{~B}$ & Brombacher 1997, 2000 \\
\hline Pestenacker (D) Kr. Landsberg, Phasen I-III & $\mathrm{W}$ & 3496 & Altheim & 265 & $58.5(?)$ & many? & $2 \mathrm{~N}$ & Neef 1990; Bittmann 2001 and unpubl. \\
\hline Galgenberg (D), Pfarrkirchen Kr. Rottal-Inn & $\mathrm{D}$ & $3500 ?$ & Altheim & 7 & 27 & 2 & ? $\mathrm{H}$ & Hinton 1999 \\
\hline
\end{tabular}

Dating: ? = some uncertainties in the dating. Preservation: $\mathrm{D}=$ site on dry mineral soils with only carbonised material preserved; $\mathrm{W}=$ waterlogged preservation. The settlements of the Galgenberg in Lower Bavaria were included although the dating is not totally clear. Representativeness scale: 1 = very good systematic sampling, with samples taken from much more than 20 locations in a settlement layer, several houses sampled, usually also judgment samples taken, several sediment types represented, archaeological evaluation made, different building phases distinguished. 2 = good systematic sampling, with samples taken from at least 10 locations in a settlement layer, in most of the cases judgment samples also taken, but there is at least one methodological problem (mostly, the archaeological evaluation is absent, making it impossible to distinguish settlement phases or the ground plans of houses, only small sample volumes etc.). $3=$ very few systematically collected samples from 3-9 locations in the excavation surface, but in addition a large number of judgment samples $(>15)$ available. $4=$ only judgment samples taken, but many (far more than 20). 5 = samples taken from fewer than 6 locations in the settlement layer and/or eroded layers only represented (taken from Jacomet and Brombacher 2005)

When "naked wheat" is mentioned in the following text, this means Triticum durum Desf./turgidum L. or T. aestivum L. (tetra- or hexaploid free-threshing wheat). Where only grains are preserved this distinction is not possible; it can be done only with the help of rachis remains (Jacomet and Schlichtherle 1984; Jacomet et al. 1989, p 329; Maier 1996). In the second half of the fourth millennium cal B.c. in the sites north of the Alps, tetraploid naked wheat is mainly found (if not the only naked wheat form present).
The different forms of barley have not been listed separately. In the publications, barley remains are referred to as Hordeum vulgare L., normally meaning a six-rowed form. The morphology of the rachis remains from the settlements north of the Alps gives the impression that mainly $H$. vulgare var. nudum (naked barley) is present. There were no hints from the literature concerning the presence of $H$. distichum L. (two-rowed barley) in the period of time under consideration here. 


\begin{tabular}{|c|c|c|c|c|c|c|c|c|c|c|c|c|c|}
\hline 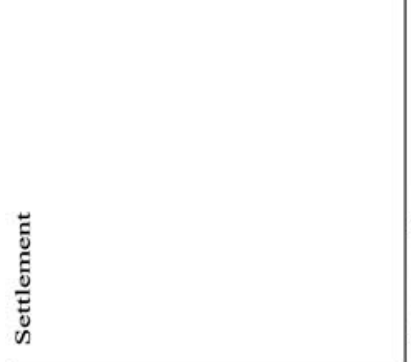 & 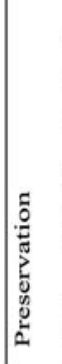 & 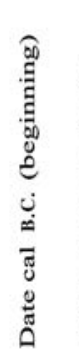 & 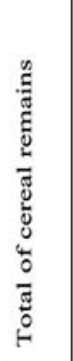 & 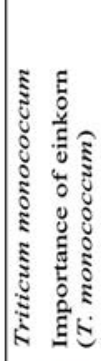 & 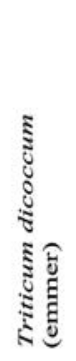 & 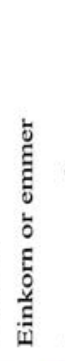 & 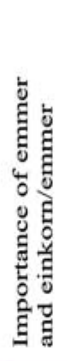 & 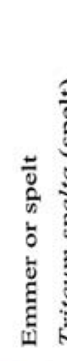 & 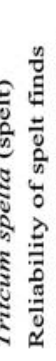 & 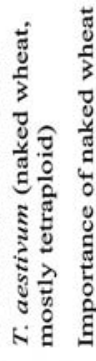 & 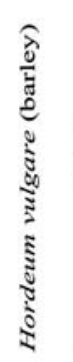 & 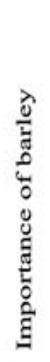 & 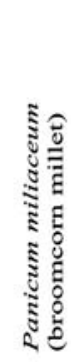 \\
\hline Hadersbach (D) Kr. Straubing-Bogen & D & 3000 & 42 & 3 & 8 & 13 & & & $7 ?$ & & 1 & & \\
\hline Seekirch (D) Stockwiesen, Kr. Biberach & W & 3030 & 1,896 & 450 & 229 & 1167 & & & & 33 & 17 & & \\
\hline Zug ZG Vorstadt 26, Rössliwiese & W(D) & ) 3050 & 1,511 & 1 & 633 & & & & & 435 & 442 & & \\
\hline Horgen ZH Scheller 3 & W & 3061 & 14,439 & 18 & 12,202 & 2176 & & 207 & $?$ & 1,509 & 327 & & \\
\hline Horgen ZH Scheller 4 & W & 3078 & 7,890 & 36 & 5,925 & 347 & & 295 & $?$ & 1,208 & 79 & & \\
\hline Pfäffikon ZH Burg & W & $3100 ?$ & 2,341 & 22 & 1,328 & 101 & & & & 586 & 304 & & \\
\hline Zürich Mozartstrasse Schicht 3 & W & 3126 & 37,411 & 99 & 20,265 & & & & & 10,824 & 6,223 & & \\
\hline Zürich KanSan Schicht 2 & W & 3126 & 75,700 & 461 & 15,184 & & & 16 & $?$ & 59,966 & 73 & & \\
\hline Allensbach (D) Strandbad unt. Schicht B & W & $3150 ?$ & 784 & 11 & 616 & & & & & 108 & 49 & & \\
\hline Twann BE mittl. Horgener KS & W & 3176 & 2,622 & 1 & 37 & 7 & & & & 1,238 & 1,339 & & \\
\hline Homstaad (D) V südl. Pfahlfeld & W & 3176 & 11,578 & 188 & 390 & 29 & & & & 9,676 & 1,295 & & \\
\hline Zürich KanSan Schicht 3 & W & 3179 & 9,109 & 73 & 6,690 & & & & & 2,269 & 77 & & \\
\hline Sipplingen (D) 0sthafen, Schicht 12-14 = u/m & W & $3200 ?$ & ? 8,281 & 41 & 3,915 & 72 & & & & 357 & 3,896 & & \\
\hline Galgenberg (D), Pfarrkirchen Kr. Rottal-Inn & D & $3200 ?$ & ? 1,583 & 4 & 51 & 15 & & & & 1,150 & 185 & & \\
\hline Zürich KanSan Schicht 4 & W & 3239 & 39,532 & 136 & 10,233 & & & & & 8,101 & 21,062 & & \\
\hline Zürich Mythenschloss Schicht 3 & W & 3240 & 135 & 1 & 79 & & & & & 52 & 3 & & \\
\hline Torwiesen II (D) Bad Buchau, Kr. Biberach & W & 3293 & 11,671 & 12 & 624 & & & & & 6,857 & 4,178 & & \\
\hline Oberrieden ZH Riet & W & $3300 ?$ & 47,000 & & $c f x$ & & & & & 47,000 & & & \\
\hline Sipplingen (D) 0sthafen, Schicht 11 = u & W & 3316 & 353 & & 222 & & & & & 131 & & & \\
\hline Wallhausen (D) Ziegelhütte, Kr. Konstanz & W & 3350 & 291 & 66 & 182 & & & & & 15 & 28 & & \\
\hline Ice Man (I), Hauslabjoch, Schnalstal & W & 3320 & 32 & $9 \times$ & 2 & & $\mathrm{X}$ & & & & 18 & $\mathrm{XX}$ & $X$ \\
\hline Wangen (D) Hinterhorn Kr. Konstanz & W & 3371 & 2,752 & 110 & 384 & & & & & 887 & 1,371 & & \\
\hline Arbon TG Bleiche 3 Flächenproben & W & 3384 & 1,829 & 89 & 568 & 269 & & & & 700 & 203 & & \\
\hline Homstaad (D) V nördl. Pfahlfeld Kr. Konstanz & W & $3400 ?$ & $? 37$ & 1 & 1 & & & & & 34 & 1 & & \\
\hline Nidau BE Schlossmatte BKW Ib, Schicht 5 & W & 3406 & 5,441 & & lcf & 1 & & & & 1,674 & 3,766 & & \\
\hline Pestenacker (D) Kr. Landsberg, Phasen I-III & W & 3496 & 707 & 170 & 518 & & & & & $>3,000$ & 8.7 & & \\
\hline Galgenberg (D), Pfarrkirchen Kr. Rottal-Inn & D & $3500 ?$ & 2,120 & 276 & 1,407 & 144 & & & $\mathrm{cf}$ & 108 & & & \\
\hline
\end{tabular}

Fig. 2 Importance of cereals in Neolithic lake dwelling sites north of the Alps (3500-3000 cal в.с.). Bright colours: not representatively investigated settlement. For more explanation, see the legend of Table 1

To study the environment and human impact on it we only include on-site data. There is an ongoing discussion about the interpretation of the off-site data in comparison with on-site results (see Rösch et al. 2002; Hosch and Jacomet 2004; Bogaard 2004). The ideas about landscape use during late Neolithic times in the northern Alpine foreland are divergent and future investigations and comparisons will have to be performed in order to arrive at reliable solutions. Therefore we have decided to exclude off-site data.

Plant nomenclature follows Zohary and Hopf (2000) for the crop plants (traditional classification for wheat and barley, p. 28), and Binz and Heitz (1990) for wild plants. Most data mentioned in the text are dendrochronological dates (solar years) B.C., for ${ }^{14} \mathrm{C}$ dates published calibrated ages are given.

\section{Results and discussion}

Domesticated plants

\section{Cereals}

Several cereal species were found with the Iceman (see Oeggl et al. 2008; Heiss and Oeggl 2008, this volume). The most important wheat was Triticum monococcum L. (einkorn). In contrast, in all the other more or less contemporary northern Alpine pile dwellings this wheat species is almost everywhere the least abundant one and it was therefore of minor importance there (Fig. 2). This seems also to be the case in northern Italian sites from the Copper Age where einkorn is found in a smaller number of settlements than emmer or barley (see Rottoli and 


\begin{tabular}{|c|c|c|c|c|c|c|c|c|c|}
\hline 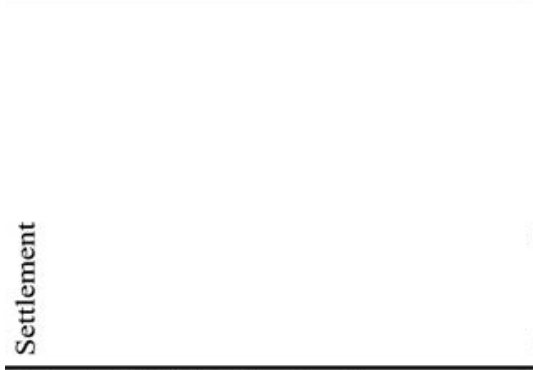 & 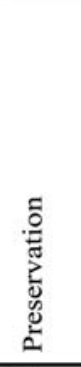 & 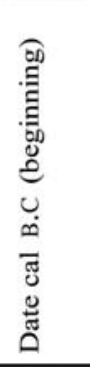 & 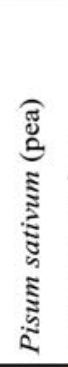 & 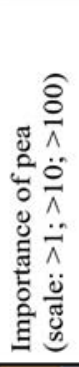 & 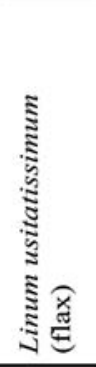 & 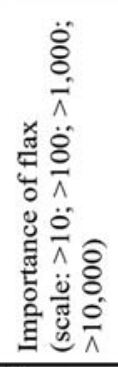 & 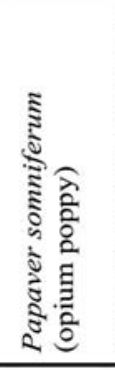 & 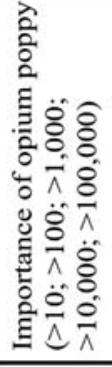 & 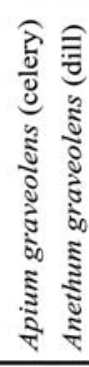 \\
\hline Hadersbach (D) Kr. Straubing-Bogen & $\mathrm{D}$ & 3000 & 1 & & & $?$ & & & \\
\hline Seekirch (D) Stockwiesen, Kr. Biberach & W & 3030 & & & H & ++ & t+ & ++ & \\
\hline Zug ZG Vorstadt 26, Rössliwiese & $\mathrm{W}(\mathrm{D})$ & 3050 & 1 & & & & & & \\
\hline Horgen ZH Scheller 3 & $\mathrm{~W}$ & 3061 & 3 & & 44,064 & & 74,721 & & 8 \\
\hline Horgen ZH Scheller 4 & W & 3078 & 4 & & 63,120 & & 10,248 & & 9 \\
\hline Pfäffikon ZH Burg & W & $3100 ?$ & 2 & & 20,943 & & 25,955 & & 1 \\
\hline Zürich Mozartstrasse Schicht 3 & W & 3126 & 981 & & 35,244 & & 124,852 & & 2 \\
\hline Zürich KanSan Schicht 2 & W & 3126 & 35 & & 20,219 & & 40,084 & & 1 \\
\hline Allensbach (D) Strandbad unt. Schicht B & W & $3150 ?$ & & & 5,226 & & 4,421 & & \\
\hline Twann BE mittl. Horgener KS & W & 3176 & & & "some" & "some" & "many" & "many" & \\
\hline Hornstaad (D) V südl. Pfahlfeld & W & 3176 & & & 598 & & 565 & & \\
\hline Zürich KanSan Schicht 3 & W & 3179 & 3 & & 42,645 & & 104,346 & & \\
\hline Sipplingen (D) Osthafen, Schicht $12-14=\mathrm{u} / \mathrm{m}$ & W & $3200 ?$ & & & 5,771 & & 10,868 & & \\
\hline Galgenberg (D), Pfarrkirchen Kr. Rottal-Inn & $\mathrm{D}$ & $3200 ?$ & 1 & & 6 & & & & \\
\hline Zürich KanSan Schicht 4 & W & 3239 & 78 & & 42,713 & & 44,071 & & 2 \\
\hline Zürich Mythenschloss Schicht 3 & W & 3240 & 1 & & 732 & & 5,381 & & \\
\hline Torwiesen II (D) Bad Buchau, Kr. Biberach & W & 3293 & & & 20,564 & & 7,672 & & \\
\hline Oberrieden ZH Riet & W & $3300 ?$ & & & & & & & \\
\hline Sipplingen (D) Osthafen, Schicht $11=u$ & W & 3316 & & & 244 & & 116 & & \\
\hline Wallhausen (D) Ziegelhütte, Kr. Konstanz & W & 3350 & & & 4,459 & & 1,339 & & \\
\hline Ice Man (I), Hauslabjoch, Schnalstal & W & 3320 & & & 1 & + & 2 & + & \\
\hline Wangen (D) Hinterhorn Kr. Konstanz & W & 3371 & 1 & & 5,766 & & 5,561 & & \\
\hline Arbon TG Bleiche 3 Flächenproben & W & 3384 & 3 & & 6,808 & & 2,955 & & 1 \\
\hline Hornstaad (D) V nördl. Pfahlfeld Kr. Konstanz & $\mathrm{W}$ & $3400 ?$ & & & 66 & & 148 & & \\
\hline Nidau BE Schlossmatte BKW Ib, Schicht 5 & W & 3406 & 2 & & 2,040 & & 2,106 & & \\
\hline Pestenacker (D) Kr. Landsberg, Phasen I-III & W & 3496 & 1 & & 1,249 & & 7 & & $1 \mathrm{cf} 22$ \\
\hline Galgenberg (D), Pfarrkirchen Kr. Rottal-Inn & $\mathrm{D}$ & $3500 ?$ & $1 \mathrm{cf}$ & & 6 & & & & \\
\hline
\end{tabular}

Fig. 3 Importance of pea, flax and opium poppy in Neolithic lake dwelling sites north of the Alps (3500-3000 cal B.c.). Bright colours: not representatively investigated settlement (for explanations, see

Castiglioni 2008, this volume). An interpretation of this result is not possible at the moment.

The most important wheat species during the second half of the fourth millennium cal B.c. in the lake dwellings north of the Alps were Triticum dicoccum Schübl. (emmer) and T. durum Desf./turgidum L. (tetraploid naked wheat); Fig. 2. During the second half of the fourth millennium B.C., emmer becomes more and more important, but the importance of naked wheat does not change too much (Fig. 2; Jacomet 2006). Whereas emmer was found with the Iceman too, naked wheat is absent. This coincides better with the known Copper Age cereal spectra from south of the Alps (see Rottoli and Castiglioni 2008, this volume).

The largest proportion of the cereals found with the Iceman consists of naked barley. This is not astonishing because on both sides of the Alps Hordeum vulgare L. (barley) was an important cereal in this time. Besides, legend to Table 1). Scale: total of numbers found in all samples. More explanations in the text

Panicum miliaceum L. (broomcorn millet) was also found with the Iceman (however, this identification is not completely sure; see Heiss and Oeggl 2008, this volume). This cereal is totally absent north of the Alpine chain, in the region considered here, whereas south of the Alps in northern Italy, it is found at a few places from the Copper Age onwards (see Rottoli and Castiglioni 2008, this volume). Again, this is a hint that the cereal spectra from the Iceman fit much better with northern Italian cereal spectra from the Copper Age.

All in all, these results corroborate the facts-that the Iceman came to his find site from Schnalstal to the southelaborated by the group of scientists working with several types of plant remains from the body itself (macroremains, pollen; for an overview, see Dickson et al. 2005; Müller et al. 2003; Oeggl 2000, 2001; Oeggl et al. 2008, this volume). 
Table 2 Numbers of obviously gathered plants in Neolithic lake dwelling sites north of the Alps (3500-3000 cal в.c.)

\begin{tabular}{|c|c|c|c|c|c|c|c|c|c|c|c|c|c|c|}
\hline 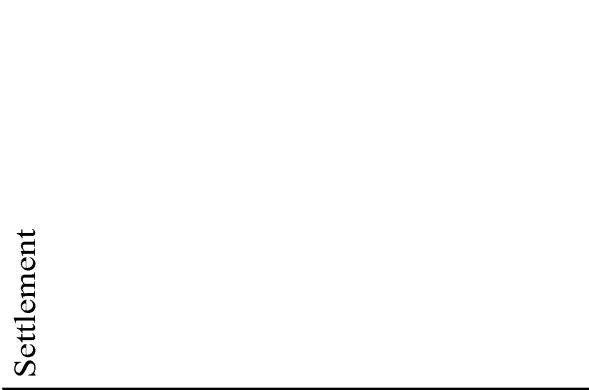 & 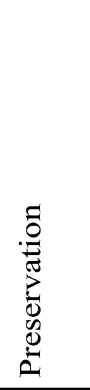 & 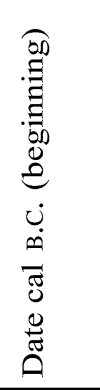 & 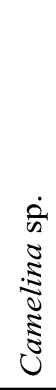 & 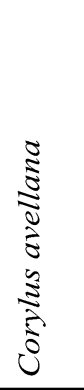 & 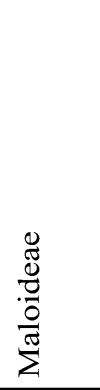 & 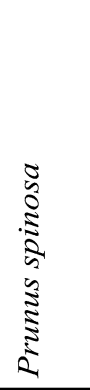 & 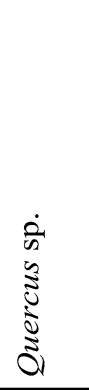 & 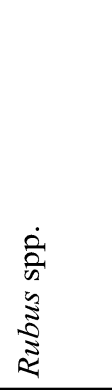 & 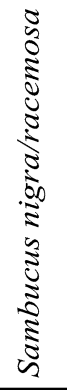 & $\begin{array}{c}0 \\
0 \\
0 \\
0 \\
0 \\
0 \\
0 \\
0 \\
0 \\
0 \\
0 \\
0\end{array}$ & $\begin{array}{l}\dot{2} \\
\hat{n} \\
\dot{0} \\
\dot{2} \\
\dot{2}\end{array}$ & 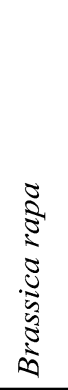 & 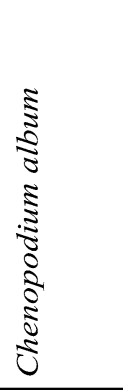 & 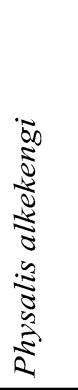 \\
\hline Hadersbach (D) Kr. Straubing-Bogen & $\mathrm{D}$ & 3000 & & $2 \mathrm{cf}$ & & & & & 1 & & & & 8 & \\
\hline Seekirch (D) Stockwiesen, Kr. Biberach & W & 3030 & & +++ & & & & +++ & +++ & +++ & & & & \\
\hline Zug ZG Vorstadt 26, Rössliwiese & $\mathrm{W}(\mathrm{D})$ & 3050 & & 1 & & & & 11 & 34 & & 1 & & & $35 \mathrm{cf}$ \\
\hline Horgen ZH Scheller 3 & $\mathrm{~W}$ & 3061 & 1 & 1,477 & 11,100 & 66 & 2,112 & 38,018 & 53 & 12,759 & 256 & 84 & 5 & 269 \\
\hline Horgen ZH Scheller 4 & W & 3078 & & 592 & 710 & 54 & 430 & 5,707 & 56 & 1,627 & 91 & 141 & 1 & 67 \\
\hline Pfäffikon ZH Burg & W & $3100 ?$ & & 1,967 & 10,610 & 214 & 259 & 7,876 & 21 & 27,244 & 206 & 168 & 10 & 178 \\
\hline Zürich Mozartstrasse Schicht 3 & W & 3126 & 2 & 311 & 6,569 & 1,246 & 175 & 15,045 & 6 & 4,453 & 491 & 129 & 462 & 1,041 \\
\hline Zürich KanSan Schicht 2 & W & 3126 & 5 & 171 & 1,001 & 40 & 65 & 6,691 & 1 & 5,185 & 31 & 422 & 180,586 & 138 \\
\hline Allensbach (D) Strandbad unt. Schicht B & W & $3150 ?$ & & + & + & + & ++ & +++ & & +++ & + & + & $+\quad-1$ & + \\
\hline Twann BE mittl. Horgener KS & $\mathrm{W}$ & 3176 & & + & + & + & + & + & + & + & + & + & + & + \\
\hline Hornstaad (D) V südl. Pfahlfeld & W & 3176 & & 37 & 42 & & & 53 & & 6 & 6 & & 2 & 1 \\
\hline Zürich KanSan Schicht 3 & $\mathrm{~W}$ & 3179 & 34 & 545 & 3,606 & 190 & 1,382 & 11,940 & 2 & 11,923 & 202 & 237 & 787 & 346 \\
\hline Sipplingen (D) Osthafen, Schicht 12-14 = u/m & $\mathrm{W}$ & $3200 ?$ & & + & + & + & & +++ & + & +++ & + & 15 & 123 & + \\
\hline Galgenberg (D), Pfarrkirchen Kr. Rottal-Inn & $\mathrm{D}$ & $3200 ?$ & & & & & & & 1 & & & 23 & & \\
\hline Zürich KanSan Schicht 4 & $\mathrm{~W}$ & 3239 & 11 & 349 & 654 & 30 & 8 & 5,872 & 1 & 2,190 & 58 & 257 & 69 & 50 \\
\hline Zürich Mythenschloss Schicht 3 & W & 3240 & & 1 & 86 & & & 426 & & & 1 & 7 & & \\
\hline Torwiesen II (D) Bad Buchau, Kr. Biberach & $\mathrm{W}$ & 3293 & 1 & 352 & 2,498 & & & 256,968 & 35 & 125,056 & & 265 & 26 & \\
\hline Oberrieden ZH Riet & W & $3300 ?$ & & & & & & & & & & & & \\
\hline Sipplingen (D) Osthafen, Schicht $11=u$ & W & 3316 & & + & + & + & & +++ & + & +++ & + & & & + \\
\hline Wallhausen (D) Ziegelhütte, Kr. Konstanz & $\mathrm{W}$ & 3350 & & 12 & 39 & 4 & 269 & 270 & 7 & 361 & 4 & 4 & 8 & 52 \\
\hline Ice Man (I), Hauslabjoch, Schnalstal & W & 3320 & & $\mathrm{x}$ & $\mathrm{x}$ & & & & 12 & & 1 & & & \\
\hline Wangen (D) Hinterhorn Kr. Konstanz & $\mathrm{W}$ & 3371 & & 24 & 1,326 & 1 & & 375 & 20 & 159 & 1 & 11 & & \\
\hline Arbon TG Bleiche 3 Flächenproben & $\mathrm{W}$ & 3384 & 20 & 9,640 & 11,880 & 90 & 565 & 4,910 & 30 & 5,466 & 158 & 235 & 6 & 137 \\
\hline Hornstaad (D) V nördl. Pfahlfeld Kr. Konstanz & $\mathrm{W}$ & $3400 ?$ & & 3 & 13 & & & 72 & & 41 & & & 2 & 1 \\
\hline Nidau BE Schlossmatte BKW Ib, Schicht 5 & $\mathrm{~W}$ & 3406 & 2 & 50 & 107 & 24 & 19 & 1,913 & 19 & 1,643 & 9 & 26 & 6 & 391 \\
\hline Pestenacker (D) Kr. Landsberg, Phasen I-III & W & 3496 & 9 & + & $++(+)$ & & $+(+)$ & + & ++ & ++ & + & + & $++(+)$ & + \\
\hline Galgenberg (D), Pfarrkirchen Kr. Rottal-Inn & $\mathrm{D}$ & $3500 ?$ & & & & & & & & & & & & \\
\hline
\end{tabular}

There were most probably many more plants which were collected, however, their use is difficult to prove. + few; ++ moderate numbers; +++ many, in cases where not fully quantified data is available

\section{Other domesticates}

From the lake dwellings north of the Alps three other domestic plant taxa are known, Pisum sativum L. (pea), Linum usitatissimum L. (flax) and Papaver somniferum L. (opium poppy). Whereas pea is usually rare, flax and poppy are found in very large amounts (Fig. 3).

Even though peas are found rather regularly at most of the sites (Fig. 3), only once during the time span considered here do they occur in quantities greater than 50 specimens, at the Horgen culture settlement of Zürich Mozartstrasse layer 3 (around 3100 B.C.) where a store of seed was found (Dick 1989). In the settlement deposits at Arbon Bleiche 3 on Lake
Constance, which consist mainly of well-preserved organic layers, only three (carbonised) peas were detected in 3401 (!) of strongly organic, waterlogged sediment (Hosch and Jacomet 2004). Nevertheless, peas were most probably grown on a regular basis, although it is impossible to judge their exact importance. Remains of pea are under-represented, most probably for unknown taphonomic reasons; usually, seeds are well represented in carbonised state. Neither was pea found in Chalcolithic settlements south of the Alps; only Lens culinaris (lentil) and Vicia ervilia (bitter vetch) are present at one single place (see Rottoli and Castiglioni 2008, this volume). Therefore, it is no surprise that not a single remain of a pulse was found with the Iceman. 
The good representation of flax and poppy in the lake dwelling sites north of the Alps is - in contrast to pea-due to the excellent waterlogged preservation of the layers. During the fourth millennium B.C. the find densities of flax and poppy rise considerably (see, for example, Brombacher and Jacomet 1997, p. 249). This can also be seen in Fig. 3 although we used a very simplified scaling (see also Jacomet 2006). They were really important domesticates, used for several purposes (see, for example Hosch and Jacomet 2004). Both plants are strongly under-represented when plant remains are preserved only in a carbonised state. This is clearly shown by the results from the lake dwelling sites where over $95 \%$ of the flax and poppy remains are preserved in an uncarbonised state (see for example Jacomet et al. 1989, Table 32, p. 115). Therefore it is not astonishing that they are absent from the few investigated Italian Chalcolithic sites south of the Alps where only settlements on dry mineral soils have been investigated (see Rottoli and Castiglioni 2008, this volume).

A few remains of flax and poppy were found with the Iceman, so he knew and used these plants too (see Heiss and Oeggl 2008, this volume).

\section{Gathered plants from the wild}

Many remains of wild plants were found with the Iceman, which he may have used (see Heiss and Oeggl 2008, this volume). Partly, these are plants of higher alpine zones like the fruits of dwarf shrubs like Vaccinium vitis-idaea L. (cowberry) or Pinus cembra L. (Arolla pine). But plants from lower altitudes are also present like Corylus avellana (hazelnut) or Sambucus spp. (elderberry etc.). This shows that he knew and used a rather large variety of wild plants.

The results from the contemporary northern alpine lake shore settlements corroborate this fact. A very large number of the remains found there come from wild plants which had obviously been used (Table 2), and often accumulations are also found. One can assume that many more plants than those listed in Table 2 were used but often this is hard to prove (see for example Jacquat 2005). However we suggest that, at the time of the Iceman, gathered plants formed a substantial part of the diet (see for example Hosch and Jacomet 2004, pp. 138-145).

In the lake dwelling sites north of the Alps, useful plants are mostly found which had been collected in the near surroundings of the settlements. However, there are also hints of contacts by the people with higher alpine areas. It is worth mentioning the remains of Pinus cembra (Arolla pine) in the settlement of Arbon Bleiche 3 (Hosch and Jacomet 2004, p 154; Fig. 4). Also, some other plants growing at higher altitudes were found in Arbon Bleiche 3 such as Veronica alpina L. It is not clear whether the Arbon people themselves went to those places (the nearest alpine vegetation is about $35 \mathrm{~km}$ to the south), for example to pasture parts of the domestic animal herd or during hunting trips, or if traders came there from south of the Alps. The finds of some wild plants, not obviously used, point to the animal herding hypothesis. Even so, contacts to the south of the Alps are clearly proven by finds of flint from the Monti Lessini region near Lake Garda. Among these finds is an identical flint dagger to the one which the Iceman had with him (Leuzinger 2002b, Fig. 18, p. 25).

Some gathered plants have also been found at Chalcolithic sites south of the Alps (see Rottoli and Castiglioni 2008, this volume). Mostly these are the same taxa as are found north of the Alps. Normally-with a few exceptions like hazel nutshells-collected plants are under-represented at dry sites. Anyway, the list from northern Italy is rather long even though only dry sites were investigated. This suggests that wild plants also formed a substantial part of the diet there.

Daily life in a Neolithic village in the lifetime of the Alpine Iceman

In this chapter we will focus on the results of the settlement Arbon Bleiche 3 on Lake Constance which most probably existed during the lifetime of the Iceman. This very well preserved settlement, which was occupied for only 15 years, was investigated on a broad interdisciplinary scale and yielded a multitude of results regarding many different aspects of the circumstances affecting people's lives at that time (see for more details the publications of Leuzinger 2000; De Capitani et al. 2002; Jacomet et al. 2004).

Wood identifications and a dendrochronological analysis were carried out, which made it possible, for the most part, to identify the type and history of construction of each individual building. The average house measured 4 by $8 \mathrm{~m}$ and the structures were mainly made of Abies alba (silver fir), Fraxinus excelsior (ash) and, more rarely, Quercus sp. (oak). The walls of the buildings probably consisted of stakes plastered with daub and of joined boards, the cracks between which were sealed with moss (many remains of Neckera crispa were found). No information could be obtained on windows or doorways. Characteristic traces of fire detected on several silver fir boards, which suggest that they overlapped each other like shingles, can be regarded as evidence of the original roof covering. Narrow lanes running at right angles to the lakeshore separated the rows of houses. Because they are contemporary with the Iceman's life span, the houses of Arbon Bleiche 3 were taken as a standard for the reconstruction of the late Neolithic 
home village of the Iceman in the Schnalstal (Archaeoparc open air museum; see http://www.archeoparc.it). One of the houses was also reconstructed at the open-air museum at Unteruhldingen on Lake Constance (Bodensee) in Germany (Fig. 5).

Waste and faeces were dumped under and between the houses. Therefore, it was possible to reconstruct many aspects of the economy and the daily life based on samples which were systematically taken from this strongly organic waste layer (the so-called cultural layer). The economy of Arbon Bleiche 3 was based on the cultivation of domestic plants, animal husbandry and also to a large degree on gathering, hunting and fishing. The most important cultivated cereals were Triticum dicoccum (emmer) and $T$. durum or T. turgidum (a tetraploid naked wheat) as well as Hordeum vulgare (a six-rowed, most probably naked barley). Cultivation of Linum usitatissimum (flax) (Fig. 6) and Papaver somniferum (opium poppy) (Fig. 7) were also rather important.

The weed spectrum gave hints as to the location of the fields and agricultural activities. All the potential segetal plants identified (see Hosch and Jacomet 2004) mainly grow on nutrient rich soils. Therefore, areas with favourable conditions had been chosen for fields. Such places would have been available on the slightly inclined moraine immediately behind the settlement. The weed spectrum, rather different from modern pre-industrial spectra, did not provide clear indication of the sowing times. One must, however, assume that autumn and spring sown crops were cultivated. Soil preparation was effective, with tools like wooden picks or maybe an ard being used (see below, draught animals and yoke). There was no evidence for slash-and-burn agriculture (see Rösch et al. 2002). Rather, the weed spectra indicate that the fields were not established on newly cleared areas. It is much more likely that permanently and intensively cultivated plots were created,

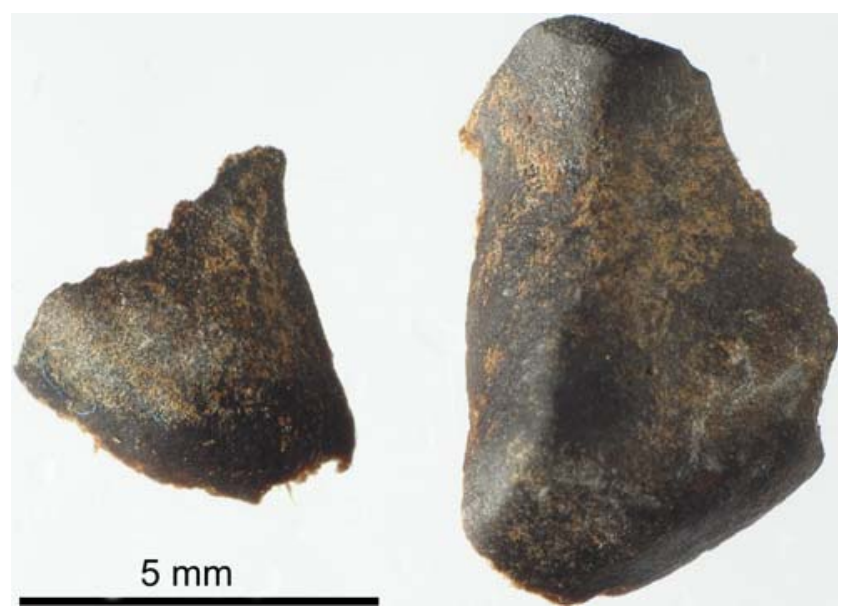

Fig. 4 Seed fragment of Pinus cembra (Arolla pine) from the settlement of Arbon Bleiche 3. Photo: D. Steiner, AATG

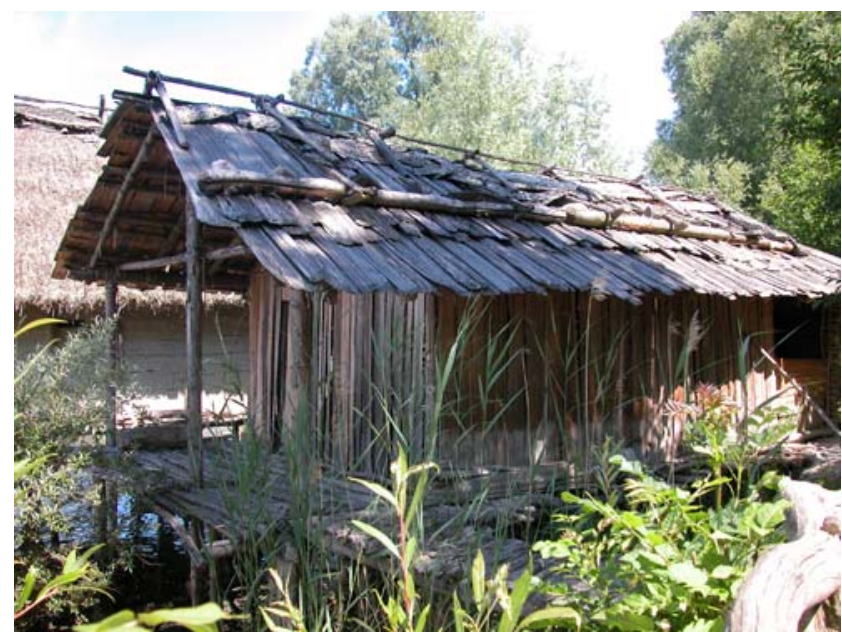

Fig. 5 Reconstructed house from Arbon Bleiche 3 in the open air museum at Unteruhldingen on Lake Constance (Bodensee), Germany. Photo: S. Jacomet

as also proposed by Bogaard (2004) for other Neolithic settlements.

Cereals and flax in particular contributed substantially to a good supply of calories. Storable foods such as acorns, wild apples and sloes as well as many berries were gathered. Gathered plants must have provided around $40 \%$ of the calories obtained from plants as reconstructed on the basis of a comparison of 1,000 grain weights of the different domestic and wild food resources (Hosch and Jacomet 2004).

The most important domestic animals were pigs and cattle, while deer and wild boar were the main types of game hunted (Deschler-Erb and Marti-Grädel 2004). Approximately half of the meat supply was game, chiefly deer. The meat supply was good, and on the basis of the minimum numbers of larger animals alone one can assume a consumption of ca. $80 \mathrm{~g}$ of meat per person per day. However, the strong emphasis on hunting suggests the occurrence of a food supply crisis, possibly due to rapid climatic deterioration that had already started while the settlement was still in existence (Magny and Haas 2004).

Fishing was also important (Hüster Plogmann 2004). On the one hand Esox lucius (pike), Perca fluviatilis (perch) and Cyprinidae (various carp-like species) were fished in areas near the shore while on the other hand fishing for Coregonus (whitefish) on the open lake was of great importance. In addition, various types of waterfowl were hunted and in early spring people also ate plenty of frogs (frogs' legs), evidence of which was found both in the form of digested frog bones and also corresponding tapeworms in human excrement (Le Bailly and Bouchet 2004).

There are hardly any differences between the houses in the range of cultivated plants consumed; all kinds of cereals were eaten in each of the houses and were probably 
also farmed by all the household units. The differences are slightly more significant regarding the gathered plants, as certain houses yielded more evidence of these than others. Another interesting fact is that bones of game were dominant in certain houses; the meat also seems to have been butchered there (hunters' houses). This is evidence of a certain degree of division of labour within the settlement.

The slaughter ages and sexes derived from the analysis of the bones suggest that cattle and goats were also used as dairy animals. In addition, sheep farming allowed for a primitive form of wool production. Pathological changes on cattle bones caused by overstraining provide evidence that cattle were obviously also used as draught animals, an assumption that is supported by a rather large maple artefact that had probably been used as a yoke (see Leuzinger 2002a, pp. 106-107). This would be the earliest evidence of draught animals in the western part of central Europe.

At least some of the foods discovered in the analyses of the plant remains and the animal bones were also found encrusted on the inside of cooking pots. The microscopic analyses (Martinez Straumann 2004) mostly showed the presence of cereals while chemical analyses were used to detect meat from domestic animals or dairy products (Spangenberg et al. 2006). The use of some animals as a source of milk, which was hypothesized from the archaeozoological results, could be proven beyond doubt by means of chemical tests. The examined pots were used to prepare stews made of cereals and meat, undoubtedly sometimes enhanced by the addition of fresh vegetables such as $R u$ mex (sorrel, dock), which is proven by the occurrence of calcium oxalate crystals. Fat from fish or game was a rare find in the contents of the pots, which suggests that these types were mainly grilled or roasted.

The analyses of various plant remains found in animal dung resulted in numerous pieces of information on the keeping of ruminants (Kühn and Hadorn 2004). Dung from small ruminants was found in large amounts and was easily recognizable by its shape. Several cowpat-shaped pieces are most probably cattle dung (Akeret and Rentzel 2001). Some fragments cannot be positively identified as cattle dung, although their composition is somewhat different from that of the dung from small animals, so they might well have been from cattle. However, on the whole, small and large ruminants were given similar fodder. All the analysed dung fragments had been produced during the winter months. Sometimes the livestock grazed in the woods near the settlement and sometimes it was foddered. The animals were given leaves from various deciduous trees, silver fir, mistletoe and ivy. In late winter they were also fed with the nutritious catkins from hazel and other early flowering trees and shrubs. Cattle fodder was somewhat more varied than that given to the sheep and goats; for instance, cereal remains were found more often in the cow-dung than in the latter.
Because evidence of harvesting leaf fodder was discovered, one would have expected that the corresponding branches would also be found within the settlement. This, however, was not the case (Zibulski 2004): only thin twigs, which must be interpreted as remnants of insulation or remains of artefacts such as baskets etc., were unearthed. Had these been fodder, they would no longer exist, because thin twigs are eaten by the animals when they are fed leaves. Therefore, leaf hay must have been stored either in a different place or even outside the settlement. The fungal spores found in the possible cattle dung suggest that leaf hay was gathered in a woodland managed by coppicing and that the animals also preferentially grazed in such areas. Also, in the charcoal material no hints of the use of twigs from leaf hay were found (A. Dufraisse, personal communication).

Animals were kept within the settlement itself only for part of the year, during the winter months. Some of them would certainly have been kept nearby during the summer

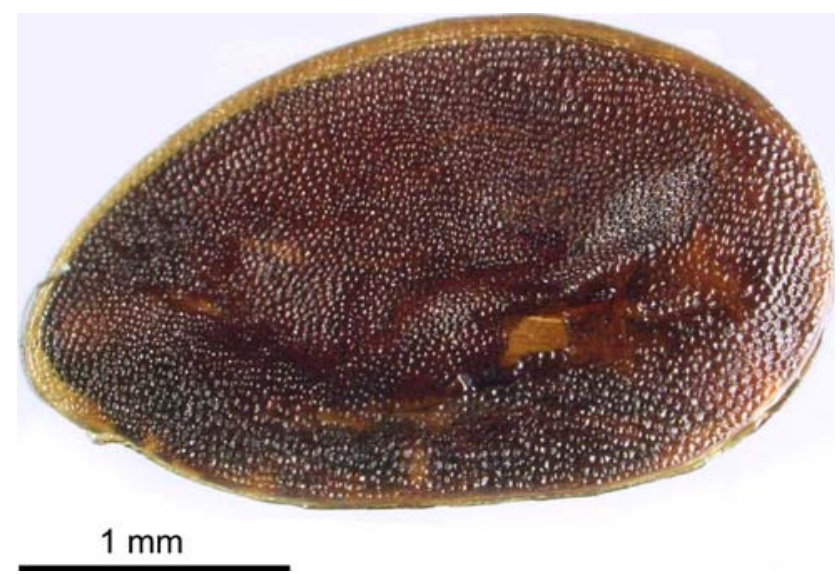

Fig. 6 Seed of Linum usitatissimum (flax) from Arbon Bleiche 3. Photo: G. Haldimann

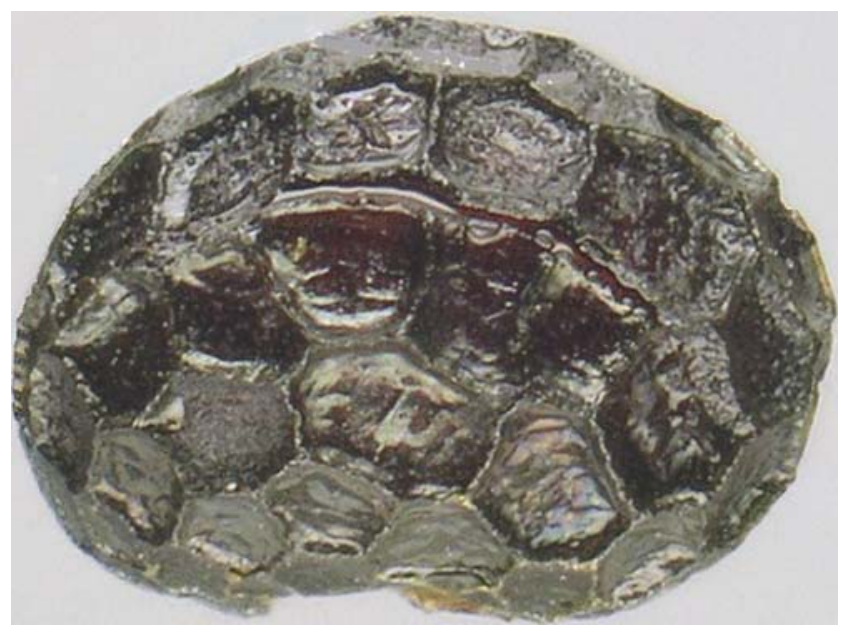

Fig. 7 Seed of Papaver somniferum (opium poppy) from Arbon Bleiche 3; length ca. $1 \mathrm{~mm}$. Photo: G. Haldimann 
months as well. This applies to the dairy animals and also to the draught animals, which were both needed in the vicinity. In addition, the finds of insects that live in dung and are active during the summer months also suggest that the livestock grazed in close proximity to the village (Lemdahl 2004). Other types of insects provide evidence that open, extensively grazed areas must have existed too. A part of the herd might have roamed further afield. Remains of alpine plants suggest that summer pastures in the Alpstein (northern Alps) as far as $35 \mathrm{~km}$ away (to the south) might have been grazed.

Hardly any parasite eggs were found in the animal dung, which means that the livestock was very healthy (Le Bailly and Bouchet 2004). This finding stands in strong contrast to the condition of the people: the high numbers and the variety of parasites detected in human coprolites point to the consumption of badly cooked or raw meat. Therefore, at least in part, the physical condition of the population was not optimal.

Based on the results described above, the immediate surroundings of the settlement must have been intensively used and impacted by humans and their livestock, but it is hardly possible to reconstruct the exact area used. It is far beyond the aim of this paper to develop hypotheses concerning this.

On the whole, the image of a self-sufficient society with many and wide-ranging contacts has emerged. The settlement was clearly settled year-round (Fig. 8). All the findings are evidence of very detailed knowledge of the natural surroundings and their deliberate use. Division of labour and specialization with high standards and a seasonally oriented, recurring and strict use of every possible source, suggest that people's actions were based on their awareness of potential problems.

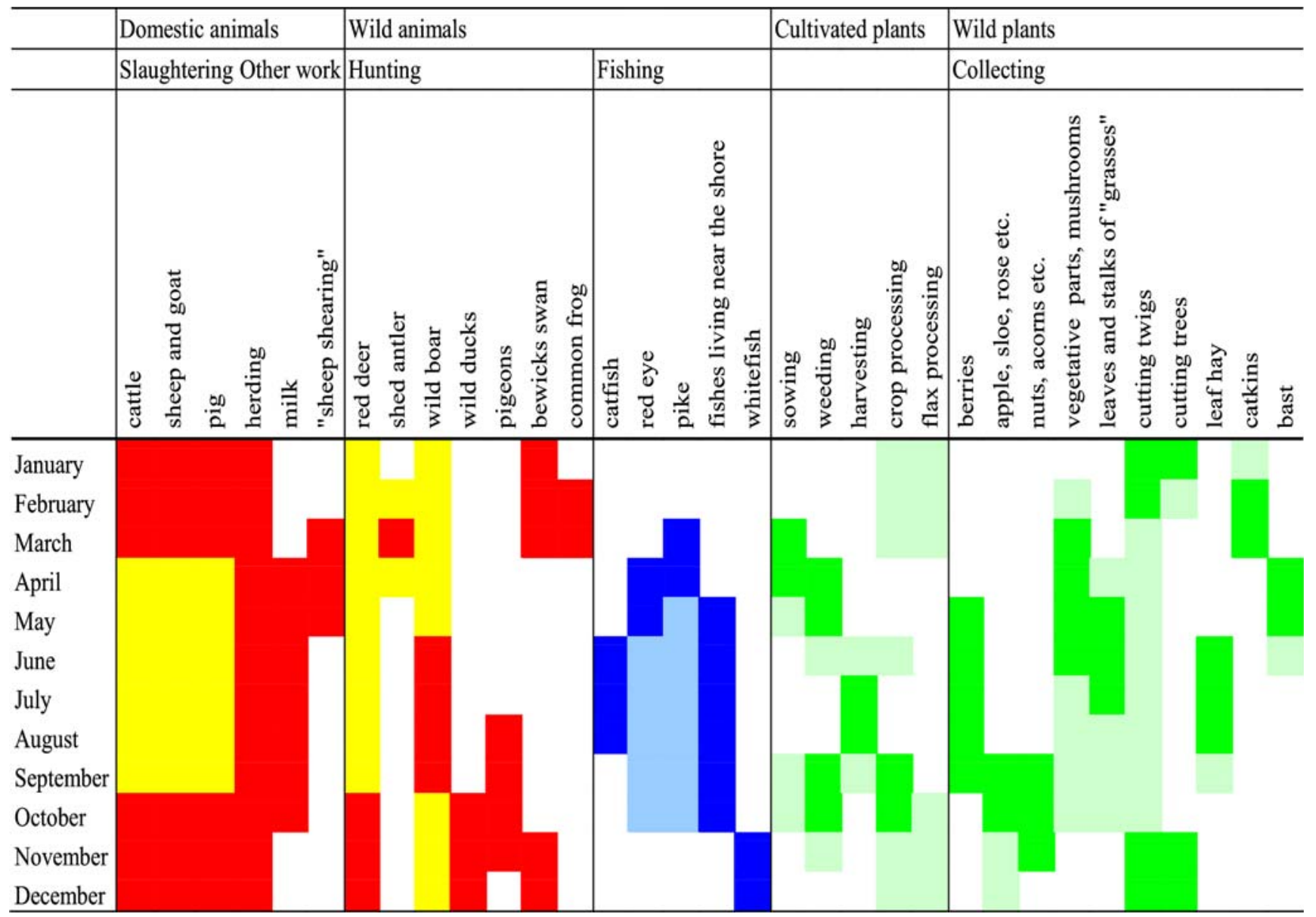

Fig. 8 Tasks of the Arbon Bleiche 3 villagers in the course of the year. The seasons during which the individual activities were carried out have been proven by the analyses. Red and yellow colouring shows animal husbandry and hunting activities. Blue, fishing activities; green, crop husbandry and plant gathering activities; darker colours show more intensive activity; lighter colours, less intensive activity. In addition there is a list of tasks that cannot be associated with a particular season: clay gathering; fabrication of pottery; gathering stones; basket weaving; building and repairing houses; collecting bracket fungus for tinder; producing cordage; carving wooden vessels and artefacts; producing and mending fish-nets; producing birch tar; producing flint artefacts; production of stone axes; manufacturing of bone and antler tools; tanning leather; weaving textiles 


\section{Conclusion}

There are striking similarities between the useful plant spectra found with the Iceman and the spectra from villages north and south of the Alps. The spectrum of domestic plants, above all the cereals, points to a southern origin, as does the evidence from the mummy itself. The Iceman lived most probably under very similar circumstances as contemporary people did in the village of Arbon Bleiche 3 . Whether he was rather a hunter or a farmer cannot be decided.

Acknowledgments I would like to thank all collaborators of the Arbon Bleiche team. Without their thorough work, finished on time, we would never have been able to draw such far-reaching conclusions. The investigations were supported by the canton of Thurgau and the Swiss National Foundation for Scientific Research (Project No. 1253-063539.00/1). I am grateful to Klaus Oeggl who provided me a table with all the plant macro remains found with the Iceman and his find-site and made some useful comments to this paper. I thank also Petra Zibulski, Felix Bittmann and Simone Riehl for allowing me to use some of their unpublished data and Alexa Dufraisse for some information on the charcoal material.

\section{References}

Akeret O, Rentzel P (2001) Micromorphology and plant macrofossil analysis of cattle dung from the Neolithic lake shore settlement of Arbon-Bleiche 3. Geoarchaeology 16:687-700

Binz A, Heitz C (1990) Schul- und Exkursionsflore für die Schweiz, mit Berücksichtigung angrenzender Gebiete. Schwabe, Basel

Bittmann F (2001) Die jungneolithische Feuchtbodensiedlung Pestenacker, Lkr. Landsberg/Lech-Auswirkungen auf die Landschaft aus botanischer Sicht. In: DFG (ed)-Graduiertenkolleg 462. Paläoökosystemforschung und Geschichte. Beiträge zur Siedlungsarchäologie und zum Landschaftswandel. Ergebnisse zweier Kolloquien in Regensburg 9-10 October 2000, 2-3 November 2000. Universitätsverlag, Regensburg, pp 93-107

Bogaard A (2004) Neolithic farming in central Europe. An archaeobotanical study of crop husbandry practices. Routledge, London

Bortenschlager S, Oeggl K (eds) (2000) The Iceman and his natural environment. (The man in the ice vol. 4) Springer, Wien

Brombacher C (2000) Archäobotanische Untersuchungen. In: Hafner A, Suter P (eds) -3400. Die Entwicklung der Bauerngesellschaften im 4. Jahrtausend v. Chr. am Bielersee aufgrund der Rettungsgrabungen von Nidau und Sutz-Lattrigen. Haupt, Bern, pp 155-168

Brombacher C, Jacomet S (1997) Ackerbau, Sammelwirtschaft und Umwelt: Ergebnisse archäobotanischer Untersuchungen. In: Schibler J, Hüster-Plogmann H, Jacomet S, Brombacher C, Gross-Klee E, Rast-Eicher A (eds) Ökonomie und Ökologie neolithischer und bronzezeitlicher Ufersiedlungen am Zürichsee. Ergebnisse der Ausgrabungen Mozartstrasse, Kanalisationssanierungen Seefeld, AKAD/Pressehaus und Mythenschloss in Zürich. Direktion der öffentlichen Bauten des Kantons Zürich, Zürich und Egg, pp 220-279

De Capitani A, Deschler-Erb S, Leuzinger U, Marti-Grädel E, Schibler J (2002) Die jungsteinzeitliche Seeufersiedlung Arbon Bleiche 3. Funde. Archäologie im Thurgau $12 \mathrm{Amt}$ für Archäologie des Kanton Thurgau, Frauenfeld
Deschler-Erb S, Marti-Grädel E (2004) Viehhaltung und Jagd. Ergebnisse der Untersuchung der handaufgelesenen Tierknochen. In: Jacomet S, Leuzinger U, Schibler J (eds) Die jungsteinzeitliche Seeufersiedlung Arbon Bleiche 3: Umwelt und Wirtschaft. Archäologie im Thurgau 12 Amt für Archäologie des Kanton Thurgau, Frauenfeld, pp 158-252

Dick M (1989) Wirtschaft und Umwelt cortaillod- und horgenzeitlicher Seeufersiedlungen in Zürich (Schweiz). Ergebnisse samenanalytischer Untersuchungen aus der prähistorischen Station Mozartstrasse. Bornträger, Stuttgart

Dickson JH, Oeggl K, Handley LL (2005) The Iceman reconsidered. Sci Am 15:4-13

Favre P (2001) Analyse pflanzlicher Grossreste aus den spätneolithischen Ufersiedlungen von Horgen-Scheller, Kanton Zürich, Schweiz. Ein Beitrag zu Umwelt- und Wirtschaftsgeschichte des 31. Jh. v. Chr. im nördlichen Alpenvorland. Doctoral thesis, University of Basel

Favre P (2002) Archäobotanik. In: Achour-Uster C, Eberli U, Ebersbach R, Favre P (eds) Die Seeufersiedlungen in Horgen. Die neolithischen und bronzezeitlichen Fundstellen Dampfschiffsteg und Scheller. Fotorotar, Zürich, pp 150-180

Furger AR (1980) Botanische Untersuchungen. In: Die Siedlungsreste der Horgener Kultur. In: Staatlicher Lehrmittelverlag Bern (ed) Die neolithischen Ufersiedlungen von Twann. Staatlicher Lehrmittelverlag, Bern, pp 125-131

Heiss AG, Oeggl K (2008) The plant remains from the Iceman sitenew results on the glacier mummy's environment. Veget Hist Archaeobot (in press)

Herbig C (2002) Archäobotanische Untersuchungen in der spätneolithischen Moorsiedlung Torwiesen II im Federseemoor (Stadt Buchau, Kreis Biberach). Magisterarbeit Universität Frankfurt

Herbig C (2006) Archaeobotanical investigations in a settlement of the Horgener culture (3300 B.c.) "Torwiesen II" at Lake Federsee, southern Germany. Environ Archaeol 11:131-142

Hinton P (1999) Charred fruits and seeds. In: Ottaway BS (eds) A changing place. The Galgenberg in Lower Bavaria from the fifth to the first millenium B.C.. BAR International Series 752, Oxford, pp 227-235

Höpfel F, Platzer W, Spindler K (eds) 1992: Der Mann im Eis, Band 1. Veröffentlichungen der Universität Innsbruck 187, Universität Innsbruck, Innsbruck

Hosch S, Jacomet S (2004) Ackerbau und Sammelwirtschaft. Ergebnisse der Untersuchung von Samen und Früchten. In: Jacomet S, Schibler J, Leuzinger U (eds) Die neolithische Seeufersiedlung Arbon Bleiche 3: Wirtschaft und Umwelt. Archäologie im Thurgau 12, Amt für Archäologie des Kanton Thurgau, Frauenfeld, pp 112-157

Hosch S, Zibulski P (2003) The influence of inconsistent wet-sieving procedures on the macroremains concentration in waterlogged sediments. J Archaeol Sci 30:849-857

Hüster-Plogmann H (2004) Fischfang und Kleintierbeute. Ergebnisse der Untersuchung von Tierresten aus den Schlämmproben. In: Jacomet S, Leuzinger U, Schibler J (eds) Die jungsteinzeitliche Seeufersiedlung Arbon Bleiche 3: Umwelt und Wirtschaft. Archäologie im Thurgau 12, Amt für Archäologie des Kanton Thurgau, Frauenfeld, pp 253-276

Jacomet S (1990) Veränderungen von Wirtschaft und Umwelt während des Spätneolithikums im westlichen Bodenseegebiet. Ergebnisse samenanalytischer Untersuchungen an einem Profilblock aus der Horgener Schichtabfolge von SipplingenOsthafen (Tauchsondierung Ruoff 1980). In: Landesdenkmalamt Baden-Württemberg, Archäologische Denkmalpflege (ed) Siedlungsarchäologie im Alpenvorland II. Berichte zu den Ufer- und Moorsiedlungen Südwestdeutschlands, pp 295-324

Jacomet S (2004) Archäobotanische Grobuntersuchung verkohlter Getreideklumpen. In: Hügin U, Michel-Tobler C (eds) 
Oberrieden ZH-Riet - eine frühhorgenzeitliche Siedlung. Jahrbuch der Schweizerischen Gesellschaft für Ur- und Frühgeschichte 87:21-23

Jacomet S (2006) Plant economy in the northern Alpine lake dwelling area - 3500-2400 B.c. cal. In: Karg S, Baumeister R, Schlichtherle H, Robinson DE (eds) Economic and environmental changes during the fourth and third Millennia B.C. Proceedings of the 25th Symposium of the AEA September 2004 in Bad Buchau, Germany. Environ Archaeol 11:64-83

Jacomet S (2007) Neolithic plant economies in the northern alpine foreland (central Europe) from 5500-3500 в.c. cal. In: Colledge $\mathrm{S}$, Conolly $\mathbf{J}$ (eds) The origin and spread of domestic plants in southwest Asia and Europe. Left Coast Press, California, pp 221-258

Jacomet S (submitted) Subsistenz und Landnutzung während des 3. Jt. v. Chr. aufgrund von archäobotanischen Daten aus der NordSchweiz und dem angrenzenden Ausland. Offa

Jacomet S, Brombacher C (2005) Reconstructing intra-site patterns in Neolithic lakeshore settlements: the state of archaeobotanical research and future prospects. In: Della Casa P, Trachsel M (eds) WES'04-Wetland economies and societies. Proceedings of the International Conference in Zurich, Chronos, Zurich, pp 69-94

Jacomet S, Brombacher C, Dick M (1989) Archäobotanik am Zürichsee. Ackerbau, Sammelwirtschaft und Umwelt von neolithischen und bronzezeitlichen Seeufersiedlungen im Raum Zürich. Ergebnisse von Untersuchungen pflanzlicher Makroreste der Jahre 1979-1988. Orell Füssli, Zurich

Jacomet S, Leuzinger U, Schibler J (2004) Die neolithische Seeufersiedlung Arbon Bleiche 3. Umwelt und Wirtschaft. Archäologie im Thurgau 12. Amt für Archäologie des Kanton Thurgau, Frauenfeld

Jacomet S, Schlichtherle H (1984) Der kleine Pfahlbauweizen Oswald Heers - neue Untersuchungen zur Morphologie neolithischer Nacktweizen-Ähren. In: Van Zeist WA, Casparie WA (eds) Plants and ancient man. Proceedings of the sixth symposium of the international work group for palaeoethnobotany 1983 in Groningen. Balkema, Rotterdam, pp 153-176

Jacomet S, Wagner C (1987) Verkohlte Pflanzenreste aus der Horgener Kulturschicht von Zug-Vorstadt 26. Jahrbuch der Schweizerischen Gesellschaft für Ur- und Frühgeschichte $70: 175-180$

Jacquat C (2005) Ethnoarchéobotanique. L'exemple d'une plante cultivée non domestiquée. Réflexions sur la cueillette de plantes sauvages. In: Della Casa P, Trachsel M (eds) WES'04 ; wetland economies and societies. Proceedings of the International Conference Zürich, Chronos, Zurich, pp 121-128

Karg S (1990) Pflanzliche Grossreste der jungsteinzeitlichen Ufersiedlungen von Allensbach-Strandbad. Wildpflanzen und Anbaufrüchte als stratigraphische, ökologische und wirtschaftliche Informationsquellen. In: Landesdenkmalamt BadenWürttemberg (ed) Siedlungsarchäologie im Alpenvorland II. Theiss, Stuttgart, pp 113-166

Kühn M, Hadorn P (2004) Pflanzliche Makro- und Mikroreste aus Dung von Wiederkäuern. In: Jacomet S, Leuzinger U, Schibler J (eds) Die jungsteinzeitliche Seeufersiedlung Arbon Bleiche 3. Umwelt und Wirtschaft. (Archäologie im Thurgau 12) Amt für Archäologie des Kanton Thurgau, Frauenfeld, pp 327-350

Küster H (1995) Postglaziale Vegetationsgeschichte Südbayerns. Geobotanische Studien zur prähistorischen Landschaftskunde. Akademie Verlag, Berlin

Kutschera W, Müller W (2003) "Isotope language" of the Alpine Iceman investigated with AMS and MS. Nucl Instrum Methods Phys Res B 204:705-719

Le Bailly M, Bouchet F (2004) Etude paléoparasitologique des coprolithes humains. In: Jacomet S, Leuzinger U, Schibler J (eds) Die jungsteinzeitliche Seeufersiedlung Arbon Bleiche 3:
Umwelt und Wirtschaft. Archäologie im Thurgau 12, Amt für Archäologie des Kanton Thurgau, Frauenfeld, pp 372-376

Lemdahl G (2004) Insect remains. In: Jacomet S, Leuzinger U, Schibler J (eds) Die jungsteinzeitliche Seeufersiedlung Arbon Bleiche 3: Umwelt und Wirtschaft. Archäologie im Thurgau 12, Amt für Archäologie des Kanton Thurgau, Frauenfeld, pp 365371

Leuzinger U (2000) Die jungsteinzeitliche Seeufersiedlung Arbon Bleiche 3. Befunde. Archäologie im Thurgau 10. Amt für Archäologie des Kantons Thurgau, Frauenfeld

Leuzinger U (2002a) Holzartefakte. In: De Capitani A, Deschler-Erb S, Leuzinger U, Marti-Grädel E, Schibler J (eds) Die jungsteinzeitliche Siedlung Arbon Bleiche 3: Funde. Archäologie im Thurgau 12, Amt für Archäologie des Kantons Thurgau, Frauenfeld, pp 76-114

Leuzinger U (2002b) Steinartefakte. In: De Capitani A, Deschler-Erb S, Leuzinger U, Marti-Grädel E, Schibler J (eds) Die jungsteinzeitliche Siedlung Arbon Bleiche 3: Funde. Departement für Erziehung und Kultur des Kantons Thurgau, Frauenfeld, pp 2275

Magny M, Haas JN (2004) A major widespread climatic change around $5300 \mathrm{cal}$. year $\mathrm{BP}$ at the time of the Alpine Iceman. J Quatern Sci 19:423-430

Maier U (1996) Morphological studies of free-threshing wheat ears from a Neolithic site in southwest Germany, and the history of the naked wheats. Veg Hist Archaeobot 5:39-55

Maier U (2004) Archäobotanische Untersuchungen in jung- und endneolithischen Moorsiedlungen am Federsee (mit einem Beitrag von Richard Vogt). In: Köninger J, Schlichtherle H (eds) Ökonomischer und ökologischer Wandel am vorgeschichtlichen Federsee. Archäologische und naturwissenschaftliche Untersuchungen. Landesdenkmalamt Baden-Württemberg, Gaienhofen-Hemmenhofen, pp 71-159

Martinez Straumann S (2004) Makro- und mikroskopische Untersuchungen von Speisekrusten aus Keramikgefässen. In: Jacomet S, Leuzinger U, Schibler J (eds) Die neolithische Seeufersiedlung Arbon Bleiche 3. Umwelt und Wirtschaft. Archäologie im Thurgau 12, Amt für Archäologie des Kanton Thurgau, Frauenfeld, pp 277-282

Matuschik I, Schlichtherle H (eds) (2001) Zeitgenossen des Gletschermannes in Baden-Württemberg 3400-2800 v. Chr. (Austellungskatalog). Janus-Verlag, Freiburg im Breisgau

Müller W, Fricke H, Halliday AN, McCulloch MT, Wartho J-A (2003) Origin and migration of the Alpine Iceman. Science 302:862-866

Neef R (1990) Botanische Untersuchungen im jungneolithischen Pestenacker. Berichte der Römisch-Germanischen Kommission 71:381-389

Oeggl K (2000) The diet of the Iceman. In: Bortenschlager S, Oeggl $\mathrm{K}$ (eds) The Iceman and his natural environment. (The man in the Ice Vol. 4) Springer, Wien, pp 89-115

Oeggl K (2001) Pollen analyses of the Iceman's colon content. In: Goodman DK, Clarke RT (eds) Proceedings of the IX International Palynological Congress, 1996. American Association of Stratigraphic Palynologists Foundation, Houston, pp 511-516

Oeggl K, Kofler W, Schmidl A (2008) New aspects on the diet of the Neolithic Tyrolean Iceman "Ötzi". Veg Hist Archaeobot (in press)

Piening U (1981) Die verkohlten Kulturpflanzenreste aus den Proben der Cortaillod- und Horgener Kultur. In: Ammann B, Bollinger $\mathrm{T}$, Jacomet S, Liese-Kleiber H, Piening U (eds) Die neolithischen Ufersiedlungen von Twann, Bd. 14: Botanische Untersuchungen. Staatlicher Lehrmittelverlag, Bern, pp 69-88

Riehl S (1993) Botanische Grossreste aus einer neolithischen Profilabfolge. Die Horgenzeitliche Seeufersiedlung Wangen/ Bodensee. Magisterarbeit Tübingen 
Robinson DE (2003) Neolithic and Bronze Age agriculture in southern Scandinavia-recent archaeobotanical evidence from Denmark. Environ Archaeol 8:145-165

Rösch M (1990) Botanische Untersuchungen an Pfahlverzügen der endneolithischen Ufersiedlung Hornstaad-Hörnle V am Bodensee. In: Landesdenkmalamt Baden-Württemberg, Archäologische Denkmalpflege (ed) Siedlungsarchäologie im Alpenvorland II. Theiss, Stuttgart, pp 325-351

Rösch M, Ehrmann O, Herrmann L, Schulz E, Bogenrieder A, Goldammer JP, Hall M, Page H, Schier W (2002) An experimental approach to Neolithic shifting cultivation. Veg Hist Archaeobot 11:143-154

Rottoli M, Castiglioni E (2008) Prehistory of plant growing and collecting in northern Italy, based on seed remains from the early Neolithic to the Chalcolithic (c. 5600-2100 cal B.c.) Veg Hist Archaeobot (in press)

Sormaz T (2004) Absolute Datierung durch Dendrochronologie und C14-Analyen. In: Jacomet S, Leuzinger U, Schibler J (eds) Die neolithische Seeufersiedlung Arbon Bleiche 3. Umwelt und Wirtschaft. Archäologie im Thurgau 12, Amt für Archäologie des Kanton Thurgau, Frauenfeld, pp 105-111
Spangenberg JE, Jacomet S, Schibler J (2006) Chemical analyses of organic residues in archaeological pottery from Arbon Bleiche 3, Switzerland - evidence for dairying in the Late Neolithic. J Archaeol Science 33:1-13

Spindler K, Rastbichler-Zissernigg E, Wilfling H, Zur Nedden D, Nothdurfter H (eds)(1995) Der Mann im Eis. Neue Funde und Ergebnisse. The man in the ice vol 2. Springer, Wien

Spindler K, Wilfling H, Rastbichler-Zissernig E, Zur Nedden D, Nothdurfter H (eds) (1996) Human mummies. The man in the ice vol 3. Springer, Wien

Willerding U (1991) Präsenz, Erhaltung und Repräsentanz von Pflanzenresten in archäologischem Fundgut. In: Van Zeist WA, Wasylikowa K, Behre K-E (eds) Progress in Old World palaeoethnobotany. Balkema, Rotterdam, pp 25-51

Zibulski P (2004) Zweige und Knospen. In: Jacomet S, Leuzinger U, Schibler J (eds) Die neolithische Seeufersiedlung Arbon Bleiche 3. Umwelt und Wirtschaft. Archäologie im Thurgau 12, Amt für Archäologie des Kanton Thurgau, Frauenfeld, pp 313-326

Zohary D, Hopf M (2000) Domestication of plants in the Old World, 3rd edn. Oxford University Press, Oxford 